\title{
THE IMPLEMENTATION OF LEARNING STRATEGY THROUGH QUESTION STUDENT HAVE (QSH) AT VOCATIONAL SCHOOL IN BANDUNG REGENCY
}

\author{
Syarifudin, $D^{1}$., Gunawan, $\mathbf{H}^{2}$., Maulana, $\mathrm{A}^{3}$. \\ ${ }^{1}$ Cililin 2 Junior High School, Jl. Raya Rancapanggung kab. Bandung Barat \\ ${ }^{2}$ Penida 2 katapang Vocational High School, Jl. Ters. Kopo KM 13 no 247 Bandung \\ ${ }^{3}$ Assalaam Junior High School, Jl. Sasakgantung No. 12 Bandung \\ ${ }^{1}$ dindincililin@gmail.com, ${ }^{2}$ hendra@yahoo.co.id, ${ }^{3}$ agungmaul@gmail.com, \\ Received: June, 2018; Accepted: June, 2018
}

\begin{abstract}
Learning Math needs stages which is in line with mental development as well as cognitive aspect. The point of view in this implication through learning math is to encourage awareness, produce questions, able to oppose, able to predict, appreciate to the own valuable invention, encourage students to find out math stucture and design, and encourage to think critically. Moreover, students are en cou raged to analize with their assumption with credible sources, find out whether the sources are credible or not, identify and evaluate, try to implement some strategies to make the correct decision based on available assessment. One of learning stages which is offered is active learning strategy. One of the application is QSH (Question Student Have) strategy. With this method, the achievement and improvement of Mathematical critical thinking of vocational school students. Furthermore, students can easily solve their problems in (a) simplifying square root, (b) deciding sinus, cosinus, and Tangen angles, and (c) phytagoras concept.
\end{abstract}

Keywords: Critical Thinking Ability, Question Student Have (QSH)

\begin{abstract}
Abstrak
Pendidikan matematika memerlukan tahapan belajar sesuai dengan perkembangan jiwa dan kognitifnya. Implikasi dari pandangan ini terhadap pembelajaran matematika adalah mendorong rasa ingin tahu, keinginan bertanya, kemampuan menyanggah dan kemampuan memperkirakan, menghargai penemuan yang diluar perkiraan sebagai hal yang bermanfaat, mendorong siswa menemukan struktur dan desain matematika, mendorong siswa berfikir, kemampuan berpikir kritis merupakan kemampuan menelaah atau menganalisis suatu sumber, mengidentifikasi sumber yang relevan dan tidak relevan, mengidentifikasi dan mengevaluasi asumsi, menerapkan berbagai strategi untuk membuat keputusan yang sesuai dengan standar penilaian, Salah satu strategi pembelajaran yang ditawarkan adalah strategi belajar aktif (active learning strategy) salah satu aplikasi daripada active learning strategy adalah strategi QSH, dengan metode QSH Pencapaian, peningkatan dan Implentasi pembelajaran kemampuan berpikir kritis matematik siswa SMK yang menggunakan strategi pembelajaran $Q S H$ lebih baik serta kesulitan-kesulitan yang dihadapi dalam menyelesaikan soal berpikir kritis matematik yaitu: (a) Kesalahan dalam menyederhanakan bilangan bentuk akar, (b) Kesalahan dalam menentukan sudut Sinus, Cosinus dan Tangen, dan (c) Kesalahan dalam konsep phytagoras
\end{abstract}

Kata Kunci: Kemampuan berpikir kritis, Question Student Have (QSH)

How to Cite Syarifudin, D., Gunawan, H., Maulana, A. (2018). The Implementation of Learning Strategy through Question Student Have (QSH) at Vocational School in Bandung Regency. JIML, 1 (2), 116-122. 


\section{INTRODUCTION}

Math learning that called school mathematics is math subject which is taught in formal school. (Rusfendi, E 2011) Math is knowledge service like other subject such as physics, chemistry, accounting, etc. Learning math needs some stages which is in line with mental development as well as cognitive aspect. implication through learning maths is to encourage awareness, produce questions, able to oppose, able to predict, appreciate to own invention as a valuable thing, encourage students to find out math stucture and design, and encourage them to think reflectively. Based on goal achievement by (Depdiknas 2015), the goals were emphasised in (1) ability of real life problem solving on mathematics or others; (2) ability to use mathematic as communication tools; (3) ability to think logically in every situation together with thinking critically and systematically, noble, and discipline in solving the problem. On the other hand, students'mathematical comprehension is very low same with international math prestige of Indonesian students.

Coherence with TIMSS, assessment of PISA (Programme for International Student Assesment) in 2003 recomended by OECD (Organization for Economic Co-operationand Development) (Ismaimuza 2013). Whereas, that abilty is part of critical thinking. This situation is inapropriate to the main priority of education system. One of learning stateges which is offered is active learning strategy. One of the application is QSH (Question Student Have) strategy. This strategy had been developed by Melvin L Silberman. He said that QSH strategy was active learning way that not make students afraid to learn that students' needs. Based on problem background, the writer was interested in observing to The Implementation of Learning Strategy through Question Student Have (QSH) at vocational school in Bandung Regency.

The term critical thinking is usually meant with convergent thinking, logical thinking with reasoning. (Salim 2016) stated that ideally critical brainware should have 12 abilities that are classified in 5 aspects: 1. Elementary clarification, 2. The basis for the decision, 3. Inference, 4. Advanced clarification, 5. Supposition and integration. Critical thinking is the ability to analize with their assumption with credible sources, find out whether the sources are credible or not, identify and evaluate, try to implement some strategies to make the correct decision based on available assessment.

QSH is a learning strategy where students were involved actively in producing questions about subject needed. So that, their abilities were explored maximally. (Aminudin 2017). By QSH method, students' learning process was more impressing. It will construct their comprehension well. This method used a technic to get students participation through their notes. Asking ability is skill used to get answer from others. Almost all processes of evaluation, measurement, assessment, and test were done through asking. Asking question could be said as a reflection of individual awareness. While, answering indicates individual comprehension of thinking

\section{METHOD}

Method on this research is experimental method. Since there was an individual treatment where one class got learning which using Question Student Have approach and the other class used conventional learning. At the beginning and the end of learning, both classes were given test in line with research design by (Rusffendi, E 2010) :

$\begin{array}{llll}\text { A } & 0 & \text { X } & 0 \\ \text { A } & 0 & & 0\end{array}$


118 Syarifudin, D., Gunawan, H., Maulana, A. The Implementation of Learning Strategy through Question Student Have (QSH) at Vocational School in Bandung Regency

Note :

A : Getting sample from random class

$\mathrm{X} \quad$ : Learning with using Question Student Have strategy

$0 \quad$ : Items of Pretest $=$ Items of Postest

Population on this reserach was all students of Vocational school in Bandung regency who have low critical thinking ability. School that school became sample was SMK Penida 2 Katapang which represents that population. From this school were choosen two classes become sample. In random sampling technic as population has same opportunity to be a sample. Through drawing sample then had been choosen XI TKJ 1 class as class experiment which get QSH learning treatment and XI TKJ2 class as class control which get conventional learning. The reason of choosing 11 grade class is because the material which will be delivered was in that class.

\section{RESULTS AND DISCUSSION}

\section{Data Description of math critical thinking ability}

Based on collected data from this research which using Question Student Have strategy and conventional learning at pretest and postest, so it get score average and deviation standard as follow:

Tabel 1. Result of Statistical Description on Math Critical Thinking Ability

\begin{tabular}{|c|c|c|c|c|c|c|}
\hline \multirow[t]{2}{*}{ Statistics } & \multicolumn{3}{|c|}{$\begin{array}{c}\text { Learning using } \\
\text { Question Student Have }\end{array}$} & \multicolumn{3}{|c|}{ Convensional learning } \\
\hline & Pretest & Postest & Gain & Pretest & Postest & Gain \\
\hline $\mathrm{N}$ & & 35 & & & 35 & \\
\hline Mean & 3.85 & 16,23 & 0,77 & 3,65 & 12,20 & 0,52 \\
\hline Min & 0 & 14 & 0,62 & 0 & 9 & 0,31 \\
\hline $\operatorname{Max}$ & 7 & 20 & 1,00 & 5 & 17 & 0,81 \\
\hline $\begin{array}{l}\text { Std. } \\
\text { Deviation }\end{array}$ & 9,30 & 1,70 & 0,10 & 10,51 & 1,80 & 0,11 \\
\hline
\end{tabular}

Based on table 1 above, it was derived pretest score average from class experiment 3,85 and class control 3,65. It seems that there is no significant difference on both classes. Therefore, it can be concluded that the prior ability in these two classes is same. But there was different score on postest. It showed that postest score average in class experiment was 16,22 with deviation standard 1,7 and class control 12,20 with deviation standard 1,8. It means that class experiment is higher than class control, $\mathrm{N}$-gain of class experiment is 0,77 and class control is 0,52 . Therefore, it can be concluded that class experiment has math critical ability improvement better than class control. To check validity by using statictical measurement for pretest, postest, and $\mathrm{N}$-gain which using normality test, homogenity test and significance test of the score average

Data Analysis of Vocational Students' Math Critical Thinking Ability Pretest

Table 2. Analsis Result Normality test on Data Pretest of Math Critical Thinking Ability Pretest

\begin{tabular}{cccc}
\hline \multirow{2}{*}{ Class } & \multicolumn{3}{c}{ Kolmogorov-Smirnov $^{\text {a }}$} \\
\cline { 2 - 4 } & Statistic & Df & Sig. \\
\hline Experiment & 0.199 & 35 & 0.001 \\
Control & 0.256 & 35 & 0.000 \\
\hline
\end{tabular}


From table 2, data could be normally distributed, so, then continued by using nonparametric test.

Table 3. Analysis result Mann-Whitney test from pretest data of math critical thinking ability

\begin{tabular}{lr}
\hline & Pretest \\
Mann-Whitney U & $\mathbf{5 8 8 . 5 0 0}$ \\
\hline Wilcoxon W & 1218.500 \\
Z & -.2 .92 \\
Asymp. Sig. (2-tailed) & .770 \\
\hline
\end{tabular}

From Tabel 3, the prior math critical thinking ability ability which using Question

Student Have strategy was not significant different with using conventional learning. .

\section{Analyze Data Postest score of math critical thinking}

From Table 4, data was not normally distributed.

Table 4. Analysis result of normality test on Postest Data of math critical thinking ability

\begin{tabular}{lccc}
\hline \multirow{2}{*}{ Kelas } & \multicolumn{3}{c}{ Kolmogorov-Smirnov $^{\mathbf{a}}$} \\
\cline { 2 - 4 } Eksperimen & Statistic & Df & Sig. \\
\hline Kontrol & 0.153 & 35 & 0.036 \\
\hline
\end{tabular}

From Table 5, it can be concluded that students' math critical thinking ability which using Question Student Have strategy better than conventional learning.

Table 5. Analysis result Mann-Whitney test from postest data of math critical thinking ability

\begin{tabular}{lc}
\hline & Postes \\
\hline Mann-Whitney U & 62500 \\
Wilcoxon W & 692500 \\
Z & -6.506 \\
Asymp. Sig. (2-tailed) & 0.000 \\
\hline
\end{tabular}

\section{Normalized Gain Data Analysis}

From Table $6 \mathrm{~N}$-gain data of class experiment and class control was normally distributed, then continued by testing variance homogenity.

Table 6. Analysis Result Normality Test N-gain Data of math critical thinking ability

\begin{tabular}{cccc}
\hline & \multicolumn{3}{c}{ Kolmogorov-Smirnov $^{\mathbf{a}}$} \\
\hline Class & Statistic & Df & Sig. \\
\hline Experiment & 0.113 & 35 & 0.200 \\
Control & 0.099 & 35 & 0.200 \\
\hline
\end{tabular}

From table 7, N-Gain score of class experiment and class control came from same population whose homogen variance.

Table 7. Analysis Result homogenity Test N-gain Data of math critical thinking ability

\begin{tabular}{cccccc} 
Class & $\mathrm{N}$ & Significance & Statment & Conclusion \\
\hline N-Gain & Experiment & 35 & 0,225 & $\mathrm{H}_{0}$ accepted & Homogen \\
\hline
\end{tabular}


120 Syarifudin, D., Gunawan, H., Maulana, A. The Implementation of Learning Strategy through Question Student Have (QSH) at Vocational School in Bandung Regency

T-Test different average used to find out whether the improvement ability of math critical thinking which using Question Student Have strategy better than conventional learning or not. Below is tabulation of result pretest score average belong to class experiment and class control:

Table 8. Analysis Result T-Test N-gain Data of math critical thinking ability

\begin{tabular}{llccc}
\hline & Class & N & Significance & Statement \\
\hline \multirow{2}{*}{ N-Gain } & Experiment & 35 & 0,000 & $\mathrm{H}_{0}$ rejected \\
& Control & & &
\end{tabular}

From Table 8, significant score is 0,000 . If the incoherent score from hypotesis score in both class is $5 \%$, So $0,000 \leq 0,05$. Since ( $\mathrm{Sig}$ ) for these two classes are less than 0,05 . Based on criteria of the test $\mathrm{H}_{0}$ was rejected. Therefore, It can be concluded that the improvement ability of math critical thinking which using Question Student Have strategy better than conventional learning.

\section{Students' problem in doing Math question items of math critical thinking ability}

The goal of this research is to find out students problems in doing Math question items about Geometry 3D. Students' problem was marked by some mistakes in answering item of critical thinking test about Geometry 3D. furthermore, some students' mistakes as followed:

1. Mistake of simplifying the squareroot.

This mistake happens because students have less comprehend to simplify kind of squareroot on question 3. It showed on picture 1 below.

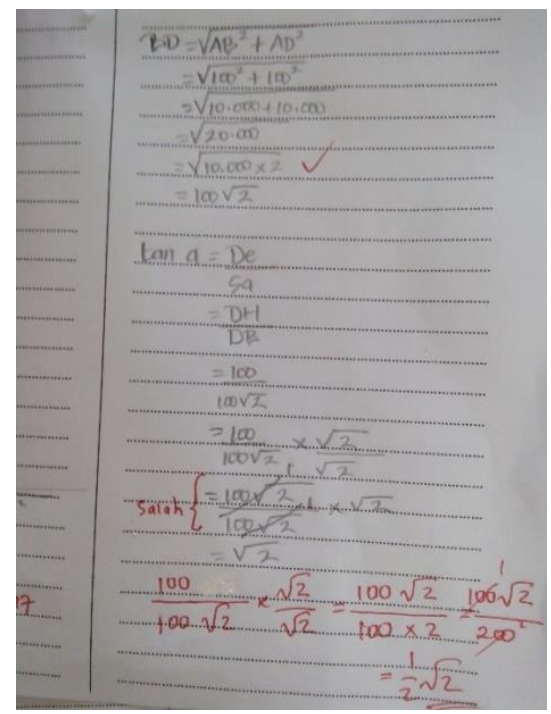

Picture 1. Mistake of simplifying the squareroot

2. Mistake of deciding Sinus, Cosinus and Tangen angle

This mistake happens because students have less comprehend to decide form of sinus, cosinus and tangen angle. This is the students' problem. So that, the best way to understand this is by memorizing the special angles. Here below is student's inappropriate answer in deciding sinus, cosinus and tangen angle: 


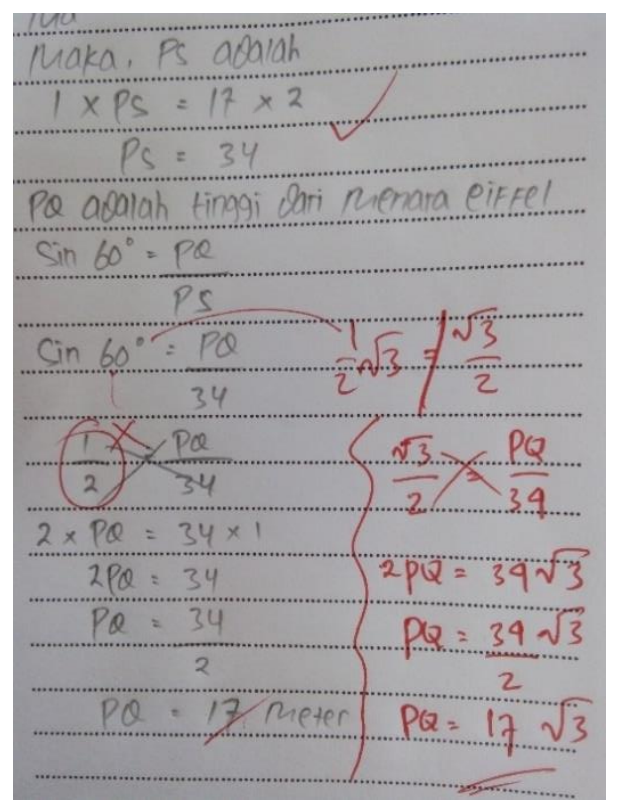

Picture 2. Mistake of deciding Sinus, Cosinus and Tangen angle

3. Mistake of Phytagoras Concept

This mistake happens because students have less comprehend to phytagoras concept. Therefore, their answer is not correct like picture below:

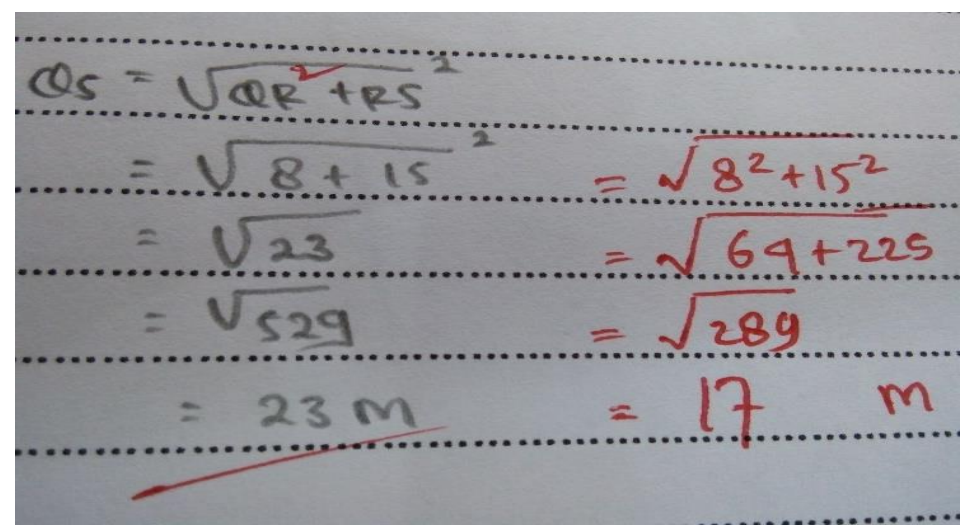

Picture 3. Mistake of Phytagoras concept

Here are tabulation result of students' mistake in doing items of the math critical thinking test class experiment and class control on Table 4.9 below :

Table 9. Percentage of students' mistake in Kesalahan doing items of the math critical thinking test

\begin{tabular}{lccccc}
\hline & \multicolumn{5}{c}{ Mistake } \\
\multicolumn{1}{c}{ Class } & item 1 & Item 2 & Item 3 & Item 4 & Item 5 \\
\hline Experiment & $7,86 \%$ & $18,57 \%$ & $25,00 \%$ & $18,57 \%$ & $24,29 \%$ \\
Control & $20,00 \%$ & $32,86 \%$ & $47,14 \%$ & $45,00 \%$ & $50,00 \%$ \\
\hline
\end{tabular}

\section{Discussion}

Based on pretest result of critical thinking ability between class experiment and class control, there was different score with close distance. This research had done for one month or twelve class meetings. Two meetings for pretest and post test and the rest meetings for learning process. The beginning of lesson started by making some small groups which consist of 5-6 
122 Syarifudin, D., Gunawan, H., Maulana, A. The Implementation of Learning Strategy through Question Student Have (QSH) at Vocational School in Bandung Regency

students who have different math skills. Each group was given worksheet to be discussed. When they get paper from other group, a student must read the question. If a student wants to find out the answer of the available question, he or she must mark the item of question by checklist mark $(\sqrt{ })$. If not, he or she can give directly to others.

Some problem happens in class experiment, students were not familiar with Question Student Have strategy during the lesson. They felt comfort only if teacher gave lesson directly and they do the worksheet individually. But three to four meetings after that, they were familiar and felt comfort and tend to more active during the lesson. As a whole, the learning activity using Question Student Have strategy has good response by students. They get more meaningful math lesson.

\section{CONCLUSION}

Based on analysis data result and finding, it can be concluded as follow: .

1. The students' improvement of math critical thinking at vocational school using QSH learning strategy had been better.

2. The Implementation of learning using Question Student Have learning strategy based on correct step with good learning process could be as one alternative way especially in learning math to improve students' critical thinking.

3. Problems that had faced difficulty in doing items of math test are (a) simplifying square root, (b) deciding sinus, cosinus, and Tangen angles, and (c) phytagoras concept.

\section{REFERENCES}

Aminudin, E. 2017. “Penerapan Model Pembelajaran Kooperatif Tipe Question Student Have (QSH) Untuk Meningkatkan Hasil Belajar Matematika Materi Pengukuran Pada Siswa Kelas IV.” BRILIANT: Jurnal Riset Dan Konseptual 2(4):434-40. Retrieved (http://www.jurnal.unublitar.ac.id/).

Depdiknas. 2015. "Pendekatan Kontekstual (Contextual Teaching and Learning)." Dirjendikdasmen.

Ismaimuza, Dasa. 2013. "Kemampuan Berpikir Kritis Dan Kreatif Matematis Siswa Smp Melalui Pembelajaran Berbasis Masalah Dengan Strategi Konflik Kognitif.” Jurnal Teknologi (Sciences and Engineering) 63(2):33-37.

Rusfendi, E, T. 2011. Naskah Akademik Matematika SMP. Bandung.

Rusffendi, E, T. 2010. Dasar-Dasar Penelitian Pendidikan Dan Bidang Non-Eksakta Lainnya. edited by Tarsito. Bandung.

Salim. 2016. "PENGEMBANGAN BAHAN AJAR MATEMATIKA BERBANTUAN SOFTWARE DERIVE UNTUK MENINGKATKAN KEMAMPUAN BERPIKIR KRITIS MATEMATIS SISWA KELAS XI IPA SMA NEGERI 1.” Indonesian Digital Journal of Mathematics and Education 3:199-207. Retrieved (http://idealmathedu.p4tkmatematika.org). 